\title{
PEMANFATAAN APLIKASI MOBILE UNTUK MEMPERCEPAT PENCARIAN TEMPAT INDEKOS BERBASIS ANDROID
}

\author{
Hendro Gunawan ${ }^{1}$, Ardi Kurniawan Hadi Saputro ${ }^{2}$ \\ ${ }^{1}$ Program Studi Sistem Informasi, Universitas Atma Jaya Yogyakarta \\ Email: hendro_gunawan@mail.uajy.ac.id \\ ${ }^{2}$ Email: asgefcos801@yahoo.co.id
}

\begin{abstract}
ABSTRAK
Purwokerto merupakan salah satu kota yang ada di Provinsi Jawa Tengah. Perkembangan Purwokerto saat ini tergolong pesat, baik di bidang ekonomi dan pendidikan. Banyak tempat indekos yang disewakan di daerah Purwokerto, terutama di sekitar kampus dan area bisnis. Namun, mayoritas pemilik tempat indekos masih memasarkan tempat indekos secara manual seperti memasang tulisan 'Terima Indekos' didepan rumah ataupun dengan cara menyewa joki.

Seiring dengan perkembangan teknologi saat ini terutama di bidang smartphone, maka banyak muncul aplikasiaplikasi yang membantu penggunanya. Untuk menjembatani kebutuhan pengguna dan penyedia indekos, maka dibutuhkan aplikasi yang dapat menampilkan informasi indekos yang ada di Purwokerto. Aplikasi yang dibangun berbasis mobile dengan sistem operasi android untuk pengguna yang ingin mencari indekos. Sedangkan untuk penyedia indekos menggunakan sistem berbasis web yang dapat melakukan update iklan indekos. Metode yang digunakan dalam penyusunan penelitian ini menggunakan model Waterfall. Tahap pengujian dilakukan dengan melakukan uji produk. Uji produk dilakukan dengan menguji aplikasi menggunakan atribut reliability and durability, conformance, serviceability, apperarance dan perceived quality.

Sistem Informasi Indekos Berbasis Android Di Purwokerto dapat membantu pengguna atau pencari indekos untuk memperoleh informasi tentang indekos dengan lebih cepat, sehingga pengguna menjadi lebih efisien dalam mencari indekos sesuai dengan yang diinginkan.
\end{abstract}

Kata Kunci : android,uji produk, indekos, waterfall.

\section{PENDAHULUAN}

Dalam era globalisasi, kebutuhan informasi sangatlah tinggi, dan penyajian informasi dituntut untuk cepat dan tepat. Pada saat ini informasi merupakan salah satu kebutuhan masyarakat yang utama di-era modern ini. Salah satu media yang dapat menjadi fasilitas untuk men-dapatkan informasi secara cepat dan tepat adalah internet. Internet adalah sebuah koneksi jaringan secara fisik dari jutaan komputer menggunakan protocol yang sama untuk sharing / transmitting informasi, selain untuk sharing / transmitting informasi internet juga digunakan untuk menghubungkan dua atau beberapa orang secara online. Internet memungkinkan akses yang bebas ke protokol dari manapun di dunia dan mampu menerima segala jenis komputer yang terhubung di dalam jaringan (Almagor, 2011).

Saat ini kita telah menyaksikan bahwa internet telah membuat kehidupan pengguna menjadi lebih mudah dan mulai menghubungkan layanan yang terpisah menjadi terhubung (misalnya: telekomunikasi, perbankan investasi, farmasi, interaksi sosial, pendidikan, hiburan) dengan perangkat (misalnya: komputer, server, ponsel pintar, bahkan chip elektronik di rumah tangga). Perkembangan yang cepat dari perangkat mobile mengarah pada pengembangan berbagai aplikasi ponsel mulai dari hiburan, pendidikan, kesehatan dan bisnis ( Kim \& Jung, 2014). Hal ini di-manfaatkan para produsen handphone untuk berlomba-lomba membuat alat bantu komunikasi yang sangat praktis dan fleksibel yaitu smartphone. Khususnya pada smartphone berbasis android yang bersifat opensource bagi pengembang untuk menciptakan ataupun mengembangkan aplikasi - aplikasi baru. Keberadaan smartphone sangatlah membantu para penggunanya untuk mendapatkan informasi dan memenuhi berbagai kebutuhannya lebih cepat dan mudah, termasuk dalam hal mencari indekos. 
Indekos merupakan salah satu tempat penyedia jasa penginapan atau tempat tinggal sementara yang terdiri dari beberapa kamar dan setiap kamar memiliki beberapa fasilitas yang ditawarkan atau disediakan dan juga mempunyai harga yang telah ditentukan oleh pemilik indekos sedangkan lama waktu penyewaan ditentukan sendiri oleh si penyewa kamar.

Purwokerto merupakan salah satu kota yang ada di Provinsi Jawa Tengah. Purwokerto memiliki banyak Universitas / Sekolah Tinggi yang berdiri. Universitas / Sekolah Tinggi yang berkualitas di purwokerto antara lain Sekolah Tinggi Ilmu Komputer (STIKOM) Yos Sudarso, Universitas Jendral Soedirman (UNSOED), Universitas Muhammadiyah Purwokerto (UMP) dan masih banyak Universitas / Sekolah Tinggi yang lainnya. Selain dari segi pendidikan, Purwokerto juga memliki fasilitas kesehatan, fasilitas public yang memadahi, serta banyak perusahaan yang berdiri dan berkembang. Banyak mahasiswa / pegawai yang berasal dari luar daerah / provinsi yang tinggal di Purwokerto untuk melangsungkan kehidupannya. Mahasiswa / pegawai yang men-cari indekos mendapatkan informasi dari teman atau mencari langsung, hal ini menjadi kurang efektif dan tidak efisien. Selain itu, budget, fasilitas, dan juga letak indekos menjadi pertimbangan. Disisi lain, pemilik indekos kesulitan dalam mempublikasikan kamar indekos yang kosong, sehingga aplikasi ini dapat membantu pemilik indekos dalam mempublikasi kamar indekosnya secara maksimal.

Dengan antusiasme mahasiswa / pegawai yang besar untuk mencari indekos, maka sangat dibutuhkannya informasi data penyewaan indekos berupa foto indekos, fasilitas indekos, daftar harga tiap indekos yang disewakan, serta peta indekos melalui Google Maps dengan bantuan GPS. Maka perlu dibangun sistem informasi pencarian tempat indekos berbasis android sehingga mahasiswa atau pegawai dapat menemukan tempat indekos yang sesuai dengan keinginannya secara efektif dan efisien di area Purwokerto.

\section{TINJAUAN PUSTAKA}

Beberapa penelitian yang telah dilakukan misalnya adalah Sistem Informasi Rumah Indekos Online Berbasis Web Dan Messaging ( Abidin, Prasetyaningrum, \& Karlita, 2012), dalam penelitian ini penulis membuat sebuah website yang menyediakan informasi rumah indekos dan penyedia dapat memasarkan melalui web. Segala transaksi dilakukan melalui web dan juga melalui SMS. Kekurangan pada penelitian ini adalah pengguna tidak dapat mencari lokasi indekos terdekat. Pengguna harus mencari melalui web kemudian memilih lokasi mana yang terdekat

Berdasar penelitian Sistem Informasi Geografis Pemetaan Tempat Indekos Berbasis Web (Kosasi, 2014), peneliti membuat sistem berbasis web yang dapat memetakan indekos di sekitar dalam sebuah peta. Kekurangan dari sistem ini adalah belum terdapat aplikasi mobile yang dapat mempermudah pengguna, untuk mengakses data indekos yang tersedia harus melalui browser sehingga tampilan sistem masih dalam bentuk web.

\section{LOCATION BASED SERVICES (LBS)}

Location Based Service (LBS) adalah teknologi yang mampu memberikan lokasi geografis dari seseorang atau objek dengan cara yang memberikan nilai kepada pelanggan, terutama melalui pemanfaatan GPS dan teknologi mobile. Dengan demikian, perkembangan LBS dapat digunakan untuk kemajuan dalam komunikasi mobile (Abbas, 2010). Kemajuan akuisisi lokasi dan komunikasi mobile teknologi telah membantu mendorong penggunaan layanan berbasis lokasi sehingga memungkinkan orang untuk menggunakan data lokasi dengan jaringan media sosial yang ada seperti Facebook, misalnya mengomentari sebuah acara di tempat yang tepat di mana 
acara tersebut terjadi, merekam rute perjalanan dengan sistem global positioning untuk berbagi pengalaman perjalanan di komunitas online. Zheng,dkk (2010) melakukan penelitian tentang geo-hidup dan menemukan bahwa kemajuan teknologi akuisisi lokasi akan memudahkan koneksi lokasi di dunia fisik serta menjembatani kesenjangan antara pengguna dan lokasi. Gambar 1 Menggambarkan LBS sebagai simpang tiga teknologi. (Madadipouya, 2014)

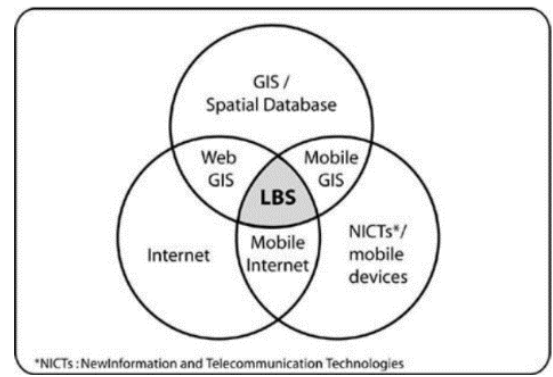

Gambar 1. LBS sebagai simpang tiga teknologi

\section{GPS}

Global Positioning System (GPS) adalah ruang berbasis sistem navigasi satelit yang menyediakan Informasi lokasi dan waktu di segala kondisi cuaca, di mana saja pada atau dekat bumi di mana ada garis lurus yang tidak terhalang dari pandangan empat atau lebih satelit GPS (ChakradharaRao, Pushpalatha, \& AdityaSundar, 2013). GPS terdiri dari tiga bagian penting, yaitu kontrol yang bertanggung jawab untuk mengawasi kinerja satelit pada orbitnya. Ruang, yaitu ruang untuk satelit beroperasi. Bisa disebut dengan orbit. Terdapat 24 satelit yang mengelilingi orbit dengan kecepatan 11,000 mil. Pengguna, yaitu bagian dari sistem karena pengguna adalah orang yang menggunakan layanan sistem GPS sehingga sistem ini bekerja (Ahamed, 2009). Metode triangulasi inilah yang digunakan satelit GPS untuk menentukan titik lokasi receiver. Untuk mendukung perhitungan triangulasi, receiver harus mengetahui dua hal: yaitu lokasi dari paling tidak tiga satelit yang dapat di akses dan jarak antara Anda dengan satelit-satelit tersebut (Hashim, Ikhmatiar, Karmin, \& Herawan, 2011).

\section{Google Maps}

Google Maps adalah layanan Google yang menawarkan teknologi pemetaan yang user-friendly dan informasi bisnis lokal - termasuk lokasi bisnis, informasi kontak, dan arah perjalanan Sedangkan Google Maps API memungkinkan pengembangan untuk mengintegrasikan Google Maps ke dalam situs web. Google Map API terdiri dari blok kode yang digunakan untuk memodifikasi peta sesuai dengan kebutuhan pengguna (Akanbi \& Agunbiade, 2013). Dengan menggunakan Google Maps API memungkinkan untuk menanamkan situs Google Maps ke dalam situs eksternal dan memungkinkan untuk untuk mengubah dan menambahkan konten ke peta (Hu \& Dai, 2013). Yang digunakan dalam Google Maps API antara lain, GeoPoint, kelas utama yang merepresentasikan latitude dan longitude. Google Maps sangat sederhana untuk disesuaikan, salah satunya dapat mencakup zooming, menyeret dan pilihan lain juga mudah digunakan. Untuk menggunakan Google Maps, kita hanya memerlukan pendaftaran pengguna untuk memperoleh kunci rahasia Google Maps API (Ahmad, Zia, \& Khalid , 2013).

\section{METODE PENELITIAN}

Dalam membuat penelitian ini, penulis menggunakan beberapa metodologi penelitian dengan studi kepustakaan untuk mengembangkan perangkat lunak ini, penulis mencari literatur atau sumber pustaka yang berhubungan dengan perangkat lunak yang akan dibuat. Sumber pustaka ini akan membantu penulis dalam penulisan teori-teori yang ada, serta dapat digunakan sebagai 
pembanding dengan penelitian yang telah dibuat. Kemudian menggunakan metode observasi, yang dilakukan untuk mengumpulkan data dengan mengadakan pengamatan langsung di lapangan, kemudian melakukan pencatatan secara sistematis terhadap objek. Mengamati keseluruhan aspek yang bersesuaian dengan kebutuhan pembuatan aplikasi. Setelah dilakukan observasi dan pengumpulan data maka akan melakukan metode pengembangan perangkat lunak, metode yang digunakan dalam membuat proyek ini adalah dengan metode waterfall.

Model Waterfall SDLC adalah proses pembangunan software secara berurutan di mana kemajuan pembangunan software seperti aliran mengalir semakin ke bawah (mirip dengan air terjun) melalui daftar tahapan yang harus dijalankan untuk berhasil membangun sebuah perangkat lunak komputer. Awalnya, model air terjun diusulkan oleh Winston W. Royce pada tahun 1970 untuk menggambarkan praktek rekayasa perangkat lunak. Model Waterfall mendefinisikan beberapa berturut-turut tahapan yang harus diselesaikan satu demi satu dan bergerak ke tahap berikutnya hanya ketika fase sebelumnya telah benar-benar dilakukan. Gambar 2 menggambarkan fase dari Model SDLC Waterfall. (Bassil , 2012)

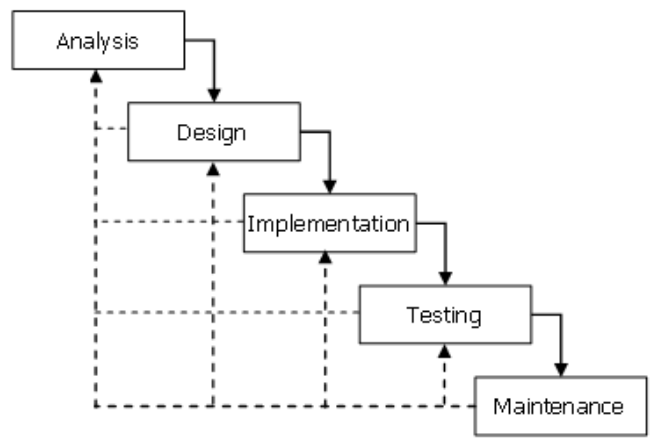

Gambar 2. Model Waterfall

Pada tahapan analisis ini penulis mengumpulkan informasi dan menganalisa kebutuhan sistem yang akan dikerjakan. Proses pengumpulan data dilakukan dengan cara wawancara yang dilakukan terhadap pemilik tempat indekos dan pengguna indekos. Tahap desain merupakan pengolahan informasi dan analisa kebutuhan sistem, hasil analisa selanjutnya dibuat desain sistem yang akan digunakan untuk mengatasi masalah yang timbul. Untuk menggambarkan sistem seperti apa yang akan dibuat, maka perlu dibuat desain pemodelan menggunakan UML (Unified Modeling Language) untuk aplikasi android yang meliputi Use Case Diagram dan Sequence Diagram, untuk sistem berbasis web digunakan DFD (Data Flow Diagram). Desain dari konsep sistem inilah yang akan digunakan sebagai pedoman pada proses berikutnya.

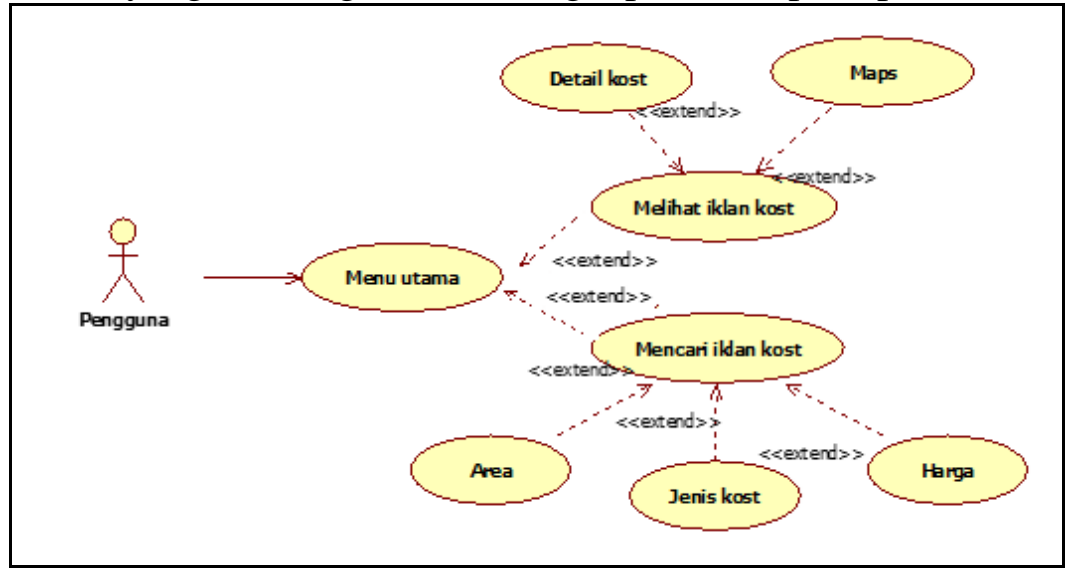

Gambar 3. Use Case Diagram 
Use case pada Gambar 3 menjelaskan pengguna masuk ke menu utama. Pada menu utama pengguna dapat melihat dan mencari iklan indekos. Di dalam iklan terdapat detail iklan indekos yang berisi tentang keterangan lengkap serta lokasi indekos tersebut yang terhubung dengan google maps. Pengguna dapat mencari iklan indekos berdasarkan area, jenis indekos dan harga.

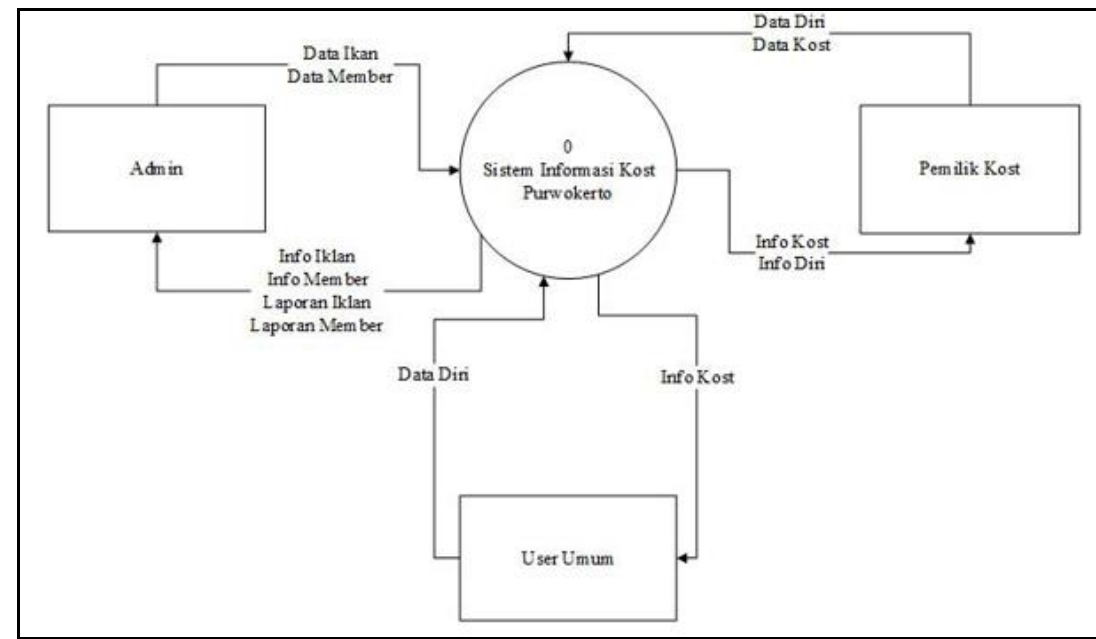

Gambar 4. Diagram Konteks Sistem Web

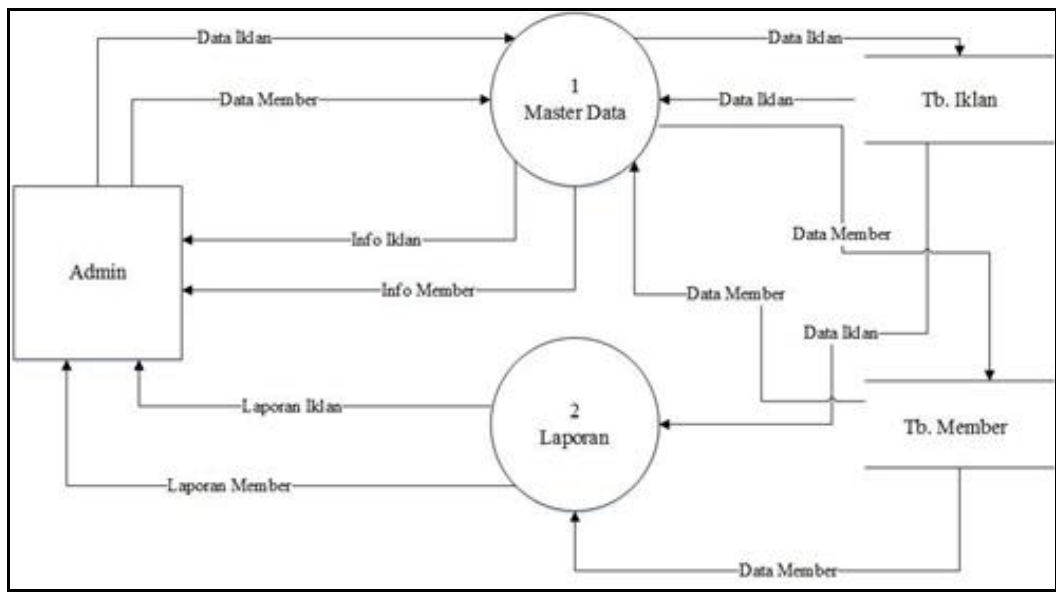

Gambar 5. DFD Level 0 Admin

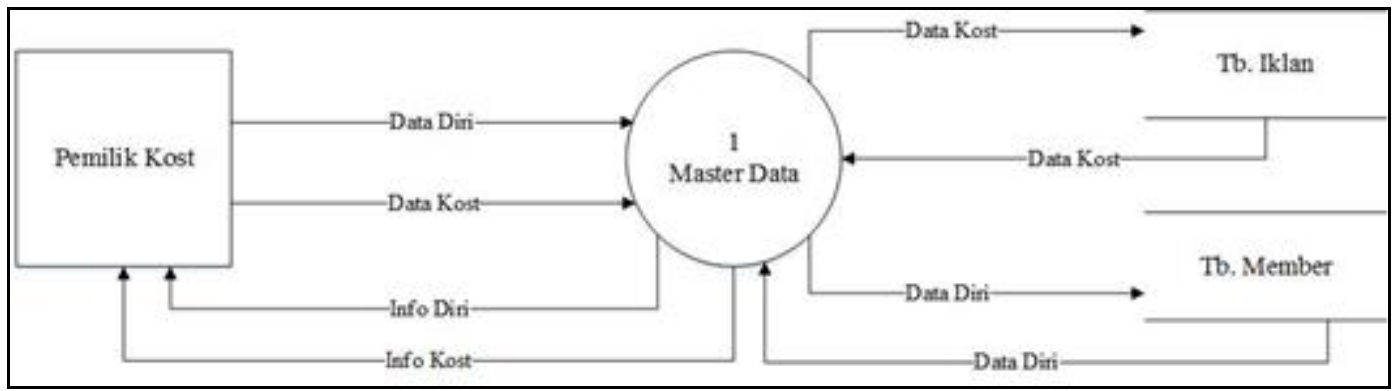

Gambar 6. DFD Level 0 Pemilik Indekos 
Gambar 4 menunjukan di dalam Sistem Informasi Indekos Purwokerto terdapat 3 entitas yaitu Admin, Pemilik Indekos dan User Umum. Entitas Admin adalah superuser di sistem ini, admin dapat menginputkan data iklan dan data member ke dalam proses Sistem Informasi Indekos Purwokerto dan memperoleh output info iklan, info member, laporan iklan dan laporan member. Entitas Pemilik Indekos memiliki hak untuk menginputkan data diri dan data indekos ke dalam Sistem Informasi Indekos Purwokerto dan memperoleh output info indekos dan info diri. Untuk menjadi pemilik indekos, user harus mendaftar terlebih dahulu ke sistem. Entitas User Umum adalah user umum pengunjung web, setiap user dapat mendaftarkan diri ke web untuk menjadi pemilik indekos agar dapat mengiklankan indekosnya. Berdasarkan DFD maka dapat dibuat beberapa table database, diantaranya adalah tabel iklan, tabel untuk menampung data iklan milik member (pemilik indekos). Data iklan meliputi: id_iklan, tanggal, id_member, nama_indekos, pemilik, no_telp, kamar_kosong, seluruh_kamar, ukuran_kamar, harga, alamat, area, kategori, fasilitas dan lokasi.

Tabel 1. Tabel Iklan

\begin{tabular}{|c|l|l|l|l|}
\hline No & \multicolumn{1}{|c|}{ Nama } & \multicolumn{1}{c|}{ Tipe } & \multicolumn{1}{c|}{ Panjang } & \multicolumn{1}{c|}{ Keterangan } \\
\hline 1 & Id_iklan* & Int & 11 & Id iklan \\
\hline 2 & Tanggal & Date & 0 & Tanggal upload \\
\hline 3 & Id_member & Int & 11 & Id member \\
\hline 4 & Nama_kost & Varchar & 50 & Nama indekos \\
\hline 5 & Pemilik & Varchar & 50 & Nama pemilik \\
\hline 6 & No_telp & Varchar & 15 & No telp pemilik \\
\hline 7 & Kamar_kosong & Int & 100 & Banyak kamar kosong \\
\hline 8 & Seluruh_kamar & Int & 100 & Banyak seluruh kamar \\
\hline 9 & Ukuran_kamar & Varchar & 100 & Ukuran kamar \\
\hline 10 & Harga & Int & 100 & Harga indekos \\
\hline 11 & Alamat & Varchar & 100 & Alamat indekos \\
\hline 12 & Area & Varchar & 255 & Area indekos \\
\hline 13 & Kategori & Varchar & 255 & Kategori indekos \\
\hline 14 & Fasilitas & Varchar & 255 & Fasilitas yang ada \\
\hline 15 & Longitude & Float & 255 & Koordinat \\
\hline 16 & Latitude & Float & 255 & Koordinat \\
\hline
\end{tabular}

Kemudian tabel member, tabel untuk menampung data member (pemilik indekos). Data member meliputi : id_member, username, password, nama_lengkap, alamat, no_telp dan email.

Tabel 2. Tabel Member

\begin{tabular}{|c|l|l|l|l|}
\hline No & \multicolumn{1}{|c|}{ Nama } & \multicolumn{1}{c|}{ Tipe } & \multicolumn{1}{c|}{ Panjang } & \multicolumn{1}{c|}{ Keterangan } \\
\hline 1 & Id_member* & Int & 10 & Id member \\
\hline 2 & Username & Varchar & 50 & Username login \\
\hline 3 & Password & Varchar & 50 & Password login \\
\hline 4 & Nama_lengkap & Varchar & 50 & Nama lengkap \\
\hline 5 & Alamat & Varchar & 100 & Alamat member \\
\hline 6 & No_telp & Varchar & 15 & No telp member \\
\hline 7 & Email & Varchar & 50 & Email member \\
\hline
\end{tabular}

Tahap implementasi dilakukan setelah perancangan desain sistem yang telah dibuat ditahapan sebelumnya. Pada tahap ini menerjemahkan hasil desain logis ke dalam kode-kode program komputer (bahasa pemprograman). Perancangan tersebut diolah dan dibangun menggunakan bahasa pemrograman melalui proses coding. Tahap pengujian dilakukan untuk memastikan program telah selesai dan menghindari terjadinya error atau kesalahan pada sistem saat dijalankan. Tahap terakhir penerapan dan pemeliharaan merupakan tahapan berupa penerapan, pemeliharaan dan perbaikan terhadap bugs maupun penambahan fitur sistem jika dibutuhkan. 


\section{HASIL DAN PEMBAHASAN}

Perangkat lunak GoletKost ini berjalan melalui media mobile device pada platform Android dengan minimum kebutuhan sistem operasi android 4.1 (Jelly Bean) hingga android 6.0 (Marshmallow).

\section{Halaman Beranda (Mobile)}

Gambar 7 merupakan tampilan awal ketika user umum membuka aplikasi informasi indekos pada androidnya. Disini pengguna dapat melihat ataupun mencari iklan indekos berdasarkan kategori indekos, area indekos dan harga indekos. Dibagian pojok atas sebelah kiri terdapat side menu yang berisikan beberapa menu dan dibagian bawahnya terdapat menu pencarian berdasarkan area dan harga.

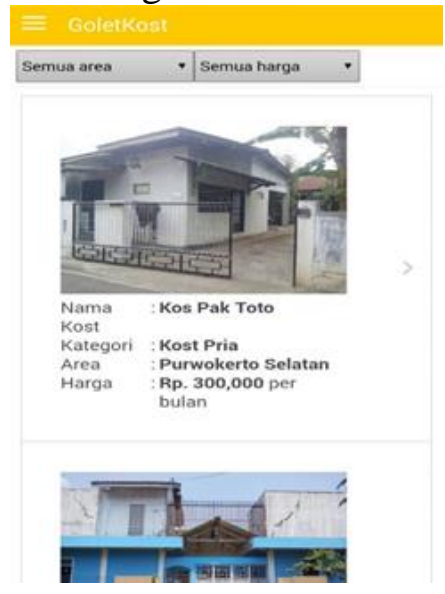

Gambar 7. Halaman Beranda

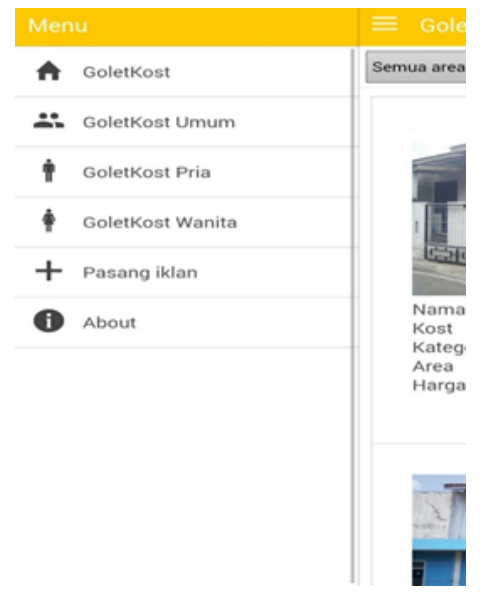

Gambar 8. Halaman Side Menu

\section{Halaman Side Menu (Mobile)}

Gambar 8 merupakan tampilan halaman menu, halaman ini menampilkan beberapa menu yaitu menu Golet kost merupakan menu beranda pada aplikasi ini, menu Golet kost Umum merupakan menu pencarian indekos berdasarkan kategori indekos umum, menu Golet kost Pria merupakan menu pencarian indekos berdasarkan kategori indekos pria, menu Golet kost Wanita merupakan menu pencarian indekos berdasarkan kategori indekos wanita, menu Pasang Iklan digunakan untuk membuka web sistem informasi indekos purwokerto, menu About digunakan untuk menampilkan informasi tentang aplikasi.

\section{Halaman Detail Iklan Indekos (Mobile)}

Gambar 9 merupakan tampilan ketika pengguna (user) memillih iklan indekos yang ada di halaman beranda. Tampilan ini berisi foto indekos dan informasi indekos secara lengkap dan dilengkapi dengan lokasi (maps) indekos tersebut. Tombol kembali digunakan untuk kembali ke halaman beranda dan tombol lokasi digunakan untuk membuka aplikasi google maps selanjutnya menampilkan lokasi indekos tersebut.

\section{Halaman Google Maps Lokasi Indekos (Mobile)}

Gambar 10 merupakan tampilan ketika pengguna (user) menekan tombol "Lokasi" pada tampilan detail iklan indekos. Tampilan google maps ini menunjukan lokasi indekos yang dipilih dan dapat membantu untuk mengarahkan pengguna agar sampai ke tempat indekos yang diinginkannya. Pengguna dapat mengaktifkan route navigasi dengan terlebih dulu mengaktifkan GPS di perangkat pengguna. 


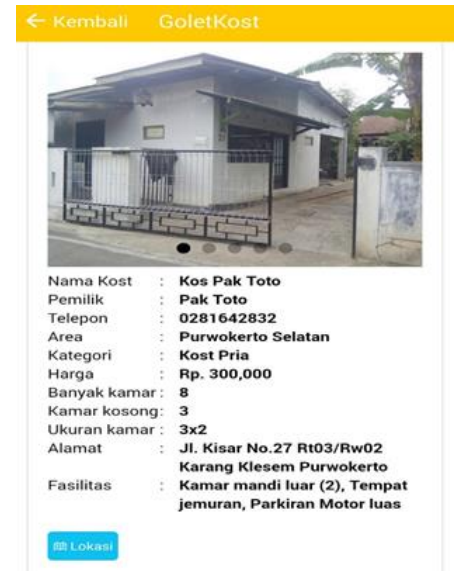

Gambar 9. Hal. Detail Iklan Indekos

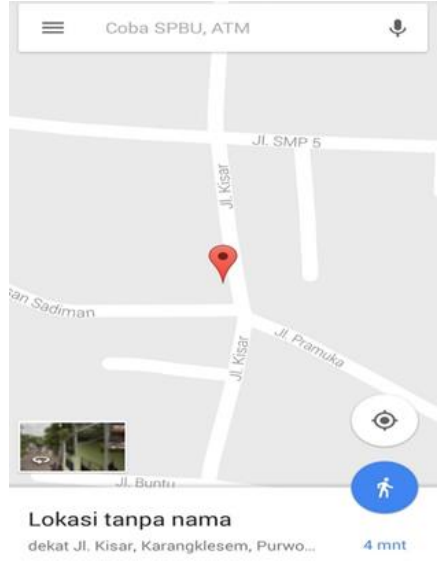

Gambar 10. Hal.Google Maps Lokasi Indekos

\section{Halaman Menu Pencarian Kategori dan Harga (Mobile)}

Gambar 11 merupakan tampilan halaman indekos umum, di dalam menu ini pengguna dapat melakukan pencarian berdasarkan area atau harga indekos. Menu pencarian ini juga berada di menu GoletKost pria dan wanita. Fasilitas pencarian ini dapat mempermudah pengguna untuk memilih indekos berdasar harga atau area.

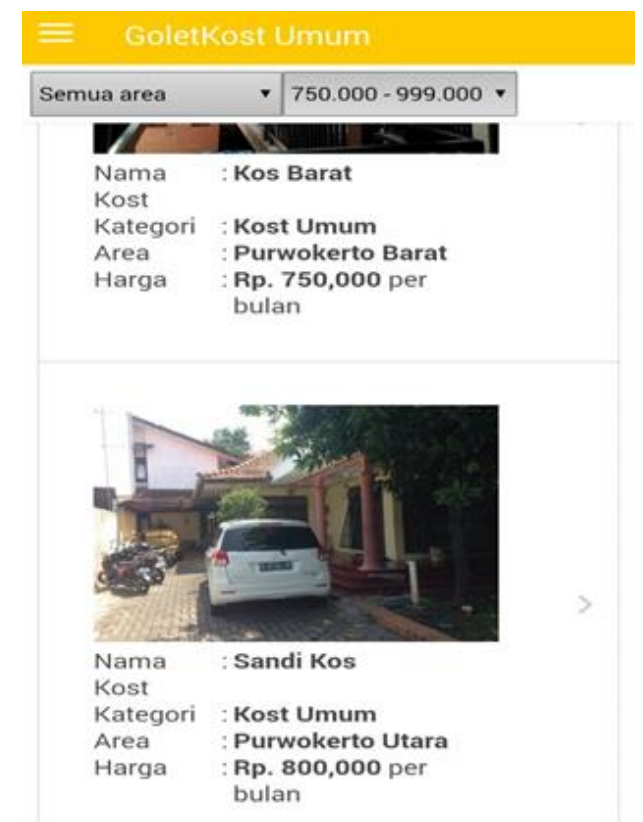

\section{Gambar 11. Halaman Menu GoletKost Umum (Mobile)}

\section{Halaman Beranda User Umum (Web)}

Gambar 12 merupakan tampilan pertama saat pengguna membuka web informasi indekos purwokerto. Di dalam halaman ini terdapat informasi iklan indekos dan beberapa menu yaitu menu beranda digunakan untuk kembali kehalaman utama, menu login digunakan untuk masuk ke halaman member (pemilik indekos) maupun ke halaman admin, menu register digunakan untuk mendaftarkan diri menjadi member (pemilik indekos), menu tentang kami digunakan untuk menampilkan informasi mengenai web sistem informasi indekos purwokerto, menu kontak kami digunakan untuk menampilkan informasi mengenai pemilik web. Di halaman ini juga terdapat fasilitas pencarian, yaitu pencarian indekos, digunakan untuk memilih kategori indekos 
yang diinginkan (Pria/Wanita/Umum), pencarian area, digunakan untuk memilih area indekos yang diinginkan (Purwokerto Utara/Selatan/Timur/Barat), pencarian harga digunakan untuk memilih range harga indekos yang diinginkan. Untuk memasang iklan indekos, harus terdaftar sebagai member terlebih dahulu. Setelah menjadi member pengguna dapat memasang iklan dan meng-update iklan indekosnya. Admin juga memiliki hak untuk menambah member dan menambah iklan indekos, selain itu admin juga dapat mencetak laporan data member dan iklan.

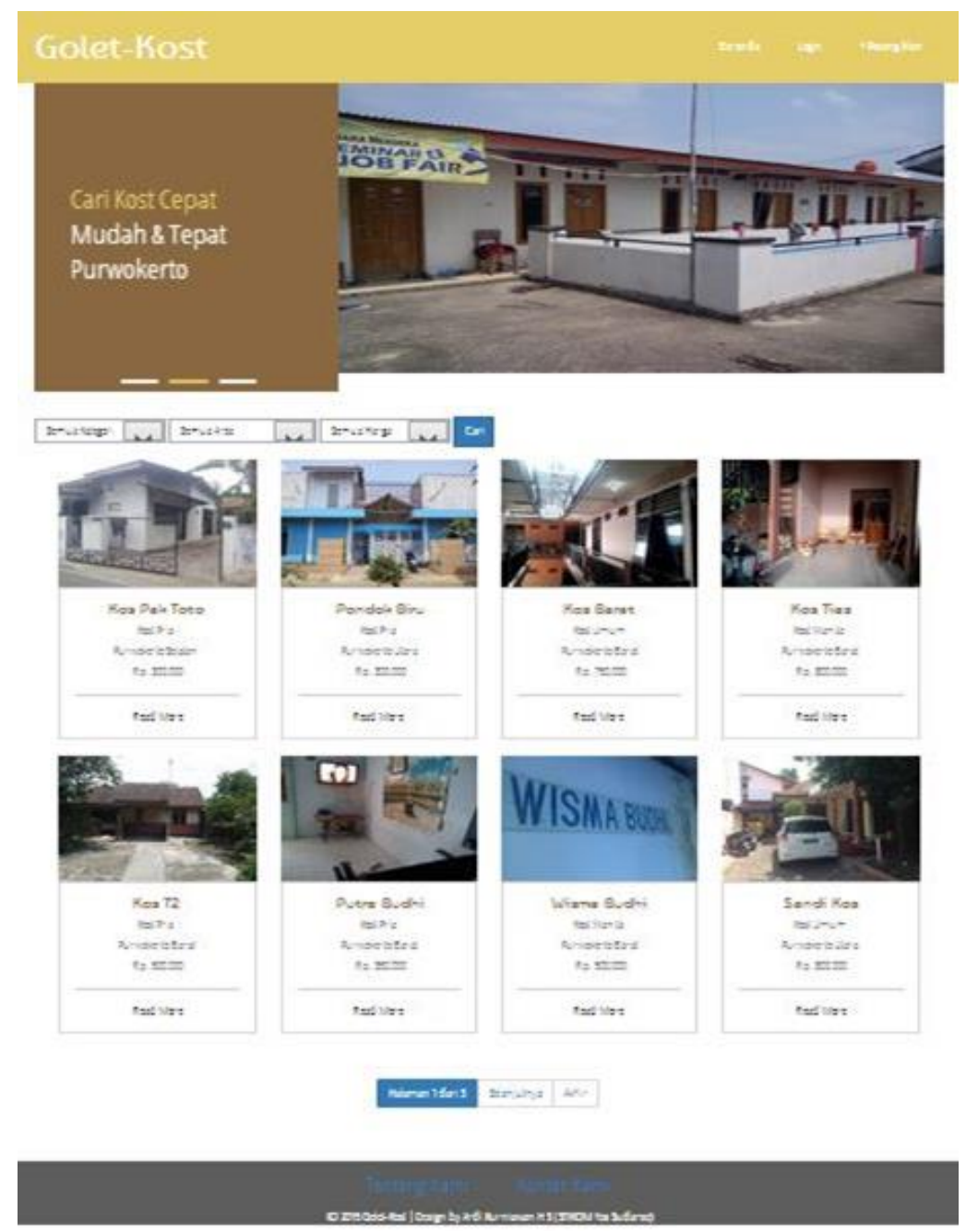

Gambar 12. Halaman Beranda User Umum (Web)

\section{Uji Produk}

Setelah sistem dibangun, dilakukan uji produk dengan mengambil sampel sebanyak 32 orang yang memiliki kemampuan atau pemahaman tentang sebuah aplikasi. Sampel mencoba aplikasi kemudian melakukan pengisian kuesioner berdasarkan komponen Operation, Reliability \& Durability, Conformance, Service Ability, Appearance dan Quality. Kuesioner berisikan 12 pertanyaan, dengan 2 pertanyaan setiap komponen. Nilai minimum untuk setiap pertanyaan adalah 0 dan maksimum 5 dengan skala Ya dan Tidak. Tabel 3 merupakan hasil dari kuesioner yang sudah diolah. 
Tabel 3. Nilai Atribut Uji Produk

\begin{tabular}{|l|r|r|r|r|r|}
\hline & D & Minimum & Maximum & Mean & Std. Deviation \\
\hline O & 32 & 5 & 10 & 8.91 & 2.100 \\
R & 32 & 5 & 10 & 8.75 & 2.200 \\
C & 32 & 5 & 10 & 8.91 & 2.100 \\
S & 32 & 5 & 10 & 8.13 & 2.459 \\
A & 32 & 5 & 10 & 7.97 & 2.495 \\
Q & 32 & 5 & 10 & 8.28 & 2.413 \\
Valid N (listwise) & 32 & & & & \\
\hline
\end{tabular}

Pada Tabel 3 nilai minimum adalah 5, nilai maksimum adalah 10 dan nilai mean dari tiap atribut lebih dari 7,5 dengan total 32 responden, dan nilai maximum dari 6 atribut yaitu 60. Selanjutnya untuk mengetahui nilai dari NUP (Nilai Uji Produk), sebelumnya kita harus mengetahui nilai RNU6A (Rataan Nilai Uji 6 Atribut) terlebih dahulu. Nilai RNU6A diperoleh dengan cara: (Faqih, 2015)

$\mathrm{RNU} 6 \mathrm{~A}=$ mean $(\mathrm{O}+\mathrm{R}+\mathrm{C}+\mathrm{S}+\mathrm{A}+\mathrm{Q})$

RNU6A $=8.91+8.75+8.91+8.13+7.97+8.28=50.9375$

Setelah RNU6A diketahui selanjutnya adalah mencari nilai dari NUP yaitu dengan cara

Nilai Uji Produk $=($ RNU6A $/$ N Max 6A $) \times 100$

Nilai Uji Produk $=(50.9375 / 60) \times 100=84.8958$

Tabel 4. Nilai Uji Produk

Descriptive Statistics

\begin{tabular}{|l|r|r|r|r|r|}
\hline & N & Minimum & Maximum & \multicolumn{1}{l|}{ Mean } & Std. Deviation \\
\hline RNU6A & 32 & 45.00 & 55.00 & 50.9375 & 2.67531 \\
NUP & 32 & 75.00 & 91.67 & 84.8958 & 4.45884 \\
Valid N (listwise) & 32 & & & & \\
\hline
\end{tabular}

Batas Nilai Uji Produk (NUP) pada penelitian ini adalah 70. Apabila NUP $\geq 70$ maka kualitas produk dinyatakan baik dan layak untuk digunakan oleh masyarakat umum, tetapi jika NUP $<70$ maka produk dinyatakan tidak layak digunakan dan harus di tinjau ulang (Faqih, 2015). Pada tabel di atas dapat dilihat nilai rataan dari NUP yaitu 84.8958, yang berarti nilai NUP $\geq 70$ maka kualitas produk dapat dinyatakan baik dan layak untuk digunakan. Selain uji produk juga dilakukan uji manfaat ke 12 pemilik indekos dan 20 pengguna indekos, uji manfaat dilakukan dengan menyebar kuesioner. Beberapa item yang diukur menggunakan standar ISO 9126, dengan karakteristik kegunaan, kemudahan, efisiensi, dan keakuratan

Tabel 5. Tabel Frekuensi Uji Manfaat

\begin{tabular}{|c|c|c|c|c|c|}
\hline \multirow{2}{*}{ Variabel } & \multirow{2}{*}{ Kriteria } & \multicolumn{3}{|c|}{ Pertanyaan } & \multirow{2}{*}{ Rata-rata } \\
\cline { 3 - 5 } & & 1 & 2 & 3 & \\
\hline \multirow{3}{*}{ Kegunaan } & $\mathrm{S}$ & 50.0 & 46.9 & 53.1 & \multirow{2}{*}{94.8} \\
\cline { 2 - 5 } & $\mathrm{SS}$ & 46.9 & 46.9 & 40.6 & \\
\cline { 2 - 5 } & Total & 96.9 & 93.8 & 93.7 & \\
\hline
\end{tabular}




\begin{tabular}{|c|c|c|c|c|c|}
\hline \multirow{3}{*}{ Kemudahan } & $\mathrm{S}$ & 37.5 & 53.1 & 53.1 & \multirow{2}{*}{94.8} \\
\cline { 2 - 5 } & $\mathrm{SS}$ & 53.1 & 46.9 & 40.6 & \\
\cline { 2 - 5 } & Total & 90.6 & 100 & 93.7 & \\
\hline \multirow{3}{*}{ Efisiensi } & $\mathrm{S}$ & 53.1 & 53.1 & 53.1 & \multirow{2}{*}{95.8} \\
\cline { 2 - 5 } & $\mathrm{SS}$ & 40.6 & 46.9 & 40.6 & \\
\cline { 2 - 5 } & Total & 93.7 & 100 & 93.7 & \multirow{2}{*}{93.8} \\
\hline & $\mathrm{S}$ & 53.1 & 46.9 & 46.9 & \\
\cline { 2 - 5 } & $\mathrm{SS}$ & 40.6 & 46.9 & 46.9 & \\
\cline { 2 - 5 } & Total & 93.7 & 93.8 & 93.8 & \\
\hline
\end{tabular}

Tabel 5 menunjukan nilai manfaat sistem yang diambil dari kuesioner yang telah dijawab oleh responden. Hasil uji manfaat yang telah dilakukan untuk mengetahui manfaat sistem bagi penggunanya juga menghasilkan nilai yang baik, yaitu: Kegunaan $=94.8 \%$, Kemudahan $=$ 94.8\% , Efisiensi $=95.8 \%$ dan Keakuratan $=93.8 \%$. Dari hasil uji manfaat tersebut dapat dikatakan bahwa sistem dirasakan dapat bermanfaat dan berguna bagi pengguna yang akan mencari atau melihat indekos di Purwokerto.

\section{KESIMPULAN DAN SARAN}

Berdasarkan hasil penelitian yang dilakukan dengan menggunakan uji produk, maka dapat disimpulkan bahwa Sistem Informasi Indekos Berbasis Android Untuk mempercepat Pencarian Indekos Di Purwokerto memiliki kualitas produk yang baik dan layak untuk digunakan oleh masyarakat umum dan juga sangat bermanfaat bagi pengguna indekos yang akan mencari atau melihat indekos di Purwokerto. Pengembangan lebih lanjut dari aplikasi ini misalnya pemilik indekos dapat mengupdate informasi indekosnya maupun memasang iklan indekos pada aplikasi android dan pencarian indekos bisa menggunakan radius dari posisi pengguna.

\section{REFERENSI}

Abidin, B., Prasetyaningrum, I., \& Karlita, T. (2012). Sistem Informasi Rumah Indekos Onlinberbasis Web Dan Messaging. Surabaya: Institut Teknologi Sepuluh Nopember .

Kim, D. K., \& Jung, J. Y. (2014). CyberOffice: A Smart Mobile Application for Instant Meetings. International Journal of Software Engineering and Its Applications, Vol.8 No.1, 43-52.

Abbas, R. (2010). Location-based Services: An Examination of User Attitudes. IEEE International Symposium on Technology and Society, 357-365. doi:10.1109/ISTAS.2010.5514620

Ahamed, R. (2009). Technological Strategy of Using Global Positioning System: an Analysis. International Journal of Engineering Science and Technology, Vol.1 No.1, 8-16.

Ahmad, W., Zia, A., \& Khalid , U. (2013, Juli). A Google Map Based Social Network (GMBSN) for Exploring Information about a Specific Territory. Journal of Software Engineering and Applications, Vol.6 No.7. doi:10.4236/jsea.2013.67043

Akanbi, \& Agunbiade. (2013, November). Integration of a city GIS data with Google Map API and Google Earth API for a web based 3D Geospatial Application. International Journal of Science and Research (IJSR), Vol.2 No.11. 
Almagor, R. C. (2011). Internet History. International Journal of Technoethics, Vol. 2 No.2, 4564. doi:10.4018/jte.2011040104

Bassil , Y. (2012). A Simulation Model for the Waterfall Software Development Life Cycle. International Journal of Engineering \& Technology (iJET), Vol.2 No.2.

ChakradharaRao, C., Pushpalatha, P., \& AdityaSundar, N. (2013). GPS Based Vehicle Navigation System Using Google Maps. International Journal of Computer Science and Information Technologies (IJCSIT), Vol.4 No.6, 979-982.

Faqih, H. (2015). Pengembangan Knowledge Management System Pada Perusahaan Multifinance: Studi Kasus Pada Bess Finance Cabang Slawi. IJSE - Indonesian Journal on Software Engineering, 1(1), 17-26.

Hashim, R., Ikhmatiar, M., Karmin, M., \& Herawan, T. (2011). Mosque Tracking on Mobile GPS and Prayer Times Synchronization for Unfamiliar Area. . International Journal of Future Generation Communication and Networking, 119, 237-246.

Hu, S., \& Dai, T. (2013, Maret). Online Map Application Development Using Google Maps API, SQL Database, and ASP.NET. International Journal of Information and Communication Technology Research, Vol.3 No.3, 102-110.

Kosasi, S. (2014, Oktober ). Sistem Informasi Geografis Pemetaan Tempat Indekos Berbasis Web. CSRID Journal, Vol.6 No.3, 171-181 .

Madadipouya, K. ( 2014, September). An Examination And Report On Potential Methods Of Strategic Location-Based Service Applications On Mobile Networks And Devices. International Journal of Managing Public Sector Information and Communication Technologies (IJMPICT), Vol.5 No.3. doi:10.5121/ijmpict.2014.5303s 